\title{
Sustainable management models: innovating through Permaculture
}

Author Details

Author 1 Name: Claudio Vitari

Department: Alternative Forms of Markets and Organizations Team, People Organizations Society department, Chair Mindfulness Well-Being at Work and Economic Peace

University/Institution: Grenoble Ecole de Management

Town/City: Grenoble

State (US only):

Country: France

Author 2 Name: Christophe David

Department: Agro-ecology And Environment,

University/Institution: ISARA Lyon, University of Lyon

Town/City: Lyon

State (US only):

Country: France

\section{Structured Abstract}

\section{Purpose}

Exploring the ways in which innovation can serve to create better and more integrated social, environmental and economic enterprises is a key challenge. How firms innovate and change depends strongly on their management models. Permaculture concepts and principles could help the transition toward more sustainability. The purpose of this study is to understand how management models could rely on Permaculture principles to facilitate innovations and changes toward sustainability.

\section{Design/methodology/approach}

This article helps meet this challenge by exploring possible innovative management models that could help in pursuing sustainability by aligning enterprises with socio-ecological realities. The possible innovative management models built on the Permaculture concepts will be the object of analysis for this study.

\section{Findings}

The literature review shows that there could be innovative management models built on the Permaculture concepts, a potential alternative to Western 'traditional' management models. They would give preference to long-term objectives, intrinsic motivation, emergent coordination, and collective wisdom in decision making. 


\section{Originality/value}

It is strategically important to find new concepts, models, methods and practices that will lead society to be ecologically sustainable and socially responsible, besides being economically efficient. These socio-cultural and economic challenges are central to the design and construction of a society in which all individuals feel integrated and responsible.

\section{Introduction}

Exploring the ways in which innovation can serve to create better and more integrated social, environmental and economic enterprises (i.e. business organizations) is a big challenge which has directed the attention of management thinkers and practitioners (Mirvis and Bradley, 2006; Senge et al., 2008; Whiteman et al., 2013). Management innovations (Birkinshaw et al., 2008) capable of establishing a balance between nature and mankind are required to overcome deadends highlighted by social, ecological and economic crises. Innovation is the application of better solutions that meet new requirements, unarticulated needs, or existing market needs. This is accomplished through more effective products, processes, services, technologies, or ideas that are readily available to markets, governments and societies (Moustaghfir and Schiuma, 2013). Innovations can radically change the ways individuals, organizations (business as well as non-business ones) and societies do things and relate with one another. Innovations are a fundamental issue for our societies as they face globalization, complex interdependencies, worldwide risks, natural resource depletions, biodiversity collapses, climate change, world population aging, or urban inhabitant evolutions (Barnosky et al., 2012; Dearing et al., 2014; Motesharrei et al., 2014; Pueyo, 2014).

Indeed an important gap in the literature still exists (Safarzyńska et al., 2012). It emerges that "we are still missing today a significant investment in research and knowledge development on questions related to the processes through which firms actually navigate the multiple change requirements to identify, experiment with, and eventually realize more sustainable models of the enterprise” (Zollo et al., 2013, p. 243). Hence it appears important to find new concepts, models, methods and practices that will lead society to be ecologically sustainable and socially responsible, besides being economically efficient. These socio-cultural and economic challenges are central to the design and construction of a society in which all individuals feel integrated and responsible.

This article explores possible innovative management models from permaculture concepts that could help in pursuing sustainability by aligning business enterprises with socio- 
ecological realities. Hence, this article answers the following research question: What might management models built on Permaculture concepts look like?

Our results show the extent to which the Permaculture management models could be alternatives to the Western 'traditional' management models, hence highlighting the interest in looking at Permaculture for guidance in developing innovative management models and enterprise models (Zollo et al., 2013). Nonetheless, first of all, the article advances a presentation of Permaculture.

\section{Permaculture concepts}

Permaculture is the portmanteau of "permanent agriculture" and was first defined by its founding authors, Mollison and Holmgren, as "an integrated, evolving system of perennial or self-perpetuating plant and animal species useful to man” (Mollison and Holmgren, 1978, p. 1).

This focus on Permaculture is justified for several different reasons that highlight the applicability and usefulness of Permaculture for organizations, and which tend to be unexplored by academics (Lockyer and Veteto, 2013) and practitioners: "there has been little hard, rigorous scientific research and few peer-reviewed papers published on the subject" (Rhodes, 2012, p. 426).

Permaculture's founding authors grounded Permaculture on strong ethical bases (Holmgren 2002; Mollison 1988) and distilled several system design principles (Holmgren, 2002; Mollison, 1988) for practical guidance (Ferguson \& Lovell 2013), partly supported by the Agro-ecology movement. The ethical bases could be directly applicable to any kind of organization, independently of its economic sector or business. Thanks to this flexibility and openness, at present Permaculture refers to a movement, a practice or a framework (Ferguson \& Lovell 2013). Nonetheless, Permaculture is united and characterized by its approach to system design (Ferguson \& Lovell 2013). This extension in the scope of Permaculture principles could make room for possible innovative management models built on the Permaculture concepts, for sustainable enterprise model innovations (Zollo et al., 2013) and sustainability in general.

From the very beginning Permaculture directed its attention mainly toward proposing and developing agricultural practices. Different authors including the founders suggested that the concept of Permaculture could have the potential to be deployed throughout every business 
domain. Permaculture could also be applied to building/housing human settlements and communities, pledging for villages, self-employment, land access, ethical investments, cooperatives, trusts, and small sizes of working groups and societies. Over time, the domains of Permaculture application extended potentially to cover any physical and energetic resource use and organization from the local to the international level (Holmgren, 2002): tools, technologies, education, health, spiritual wellbeing, finance, economics, land tenure, community governance, land and nature stewardship, infrastructures, children playgrounds, peace building, earthquake relief, finance, urban planning. For several authors, the 'Permaculture' portmanteau has lost its link to the cultivated fields of agriculture (from Latin agricultura, ager field + cultura cultivation) to refer more largely to permanent culture (Permanent Culture Now, 2014; Pezrès, 2010) and a holistic life system (Marrewijk and Werre, 2003). Given all this potential, this article looks at Permaculture as a source of possible innovative management models, through a literature review method, having Permaculture as its scope and the Birkinshaw and Goddard's management model (Birkinshaw \& Goddard, 2009a, 2009b) as the pre-structured deductive analysis framework (Miles et al., 2013).

\section{Theoretical framework and methodology}

\section{Management models}

The attention of the research is directed to the management models. The management concept may refer to the technical task of organization or denote the system of hierarchical authority. In this context, models of management become a body of technical knowledge applicable to practical situations but also ideologies aimed at establishing legitimacy and reinforcing credibility (Guillén 1994). The ideology is the foundation on which organization's members appraise how far the technical knowledge available can be applied for practical solutions. As a consequence, a management model should involve choices at the most fundamental level about how the organization will be run. This attention to the "how" allows links to be established between the sources of change (why?) and the objects of change (what?) and considers the management model as the engine of change (Zollo et al. 2013). This attention to the "how" would facilitate the study of the evolutionary processes and efforts any firm is making to evolve toward sustainable enterprise models (Zollo et al. 2013). Looking at the management models is particularly interesting as these change processes are largely contextindependent. Indeed, a management model could include knowledge related to domains such as: human relation aspects, organizational paradigms, problem-solving procedures, authority 
maintenance, production systems, organizational goals, planning, decision-making, motivation, structures, systems of governance, coordination and control (Barkema et al., 2015; Cennamo et al., 2008; Egri and Herman, 2000; Guillén, 1994; Hill and Jones, 1992; Mehri, 2006; Newman and Wallender, 1978). Specific management models are described for ecological sustainability (Egri and Herman, 2000) and social equity issues (Newman and Wallender, 1978).

\section{Birkinshaw and Goddard's management model}

The best way to understand "What might management models built on permaculture concepts look like?” is to use the proposal frame of Birkinshaw \& Goddard (2009a, 2009b).

Even this management model attracts some critiques. On the one hand, the main criticisms of Birkinshaw \& Goddard's management model concern the contingency of management, which excludes any possibility for structural changes to management and which avoids simplistic techniques and simple-minded management strategies (Hamermesh, 1996; Mintzberg, 2006, 2011). On the other hand, several authors welcomed Birkinshaw \& Goddard's management model as a tool to create value for business and society, through management innovation, firm performance, productivity growth and dynamic capabilities (van den Bosch, 2012; Shenglei and Feng, 2015; Volberda et al., 2013).

This framework still seems useful. On the one hand, it is based on three fundamental statements that are shared by the Permaculture authors: the failure of mainstream management (Barkema et al., 2015; Clegg, 2014), the devaluation of leaders (Liu et al., 2012), and the importance of information (Knippenberg et al., 2015). On the other hand, it gives the possibility to evaluate the management model on different dimensions and to improve the appreciation of the contribution of management innovations for a better world. The authors of the management model framework state that the "traditional" management models of Western economies are turned towards the alignment of short-term goals, extrinsic motivations, bureaucratic coordination, and hierarchical decision-making. Birkinshaw and Goddard foresee the evolution of management models and they also suggest the kind of management models that would be useful based on contextual condition. The so called "discovery model" is indicated as the most suitable in case of highly uncertain, ambiguous, fast-changing environments, and for organizations that are looking for new ways forward. This discovery model is an "alternative" management model; the discovery model is positioned toward the obliquity, intrinsic, emergence, and collective wisdom poles, for the 4 axes of the 
management model framework. Finally, Birkinshaw suggests that this alternative management model could be discovered in sports teams, social communities, aid organizations, or families. Can we discover other alternative management models in Permaculture?

\section{Birkinshaw and Goddard's management model framework}

This management model covers how four core sets of activities could be delivered:

1. Choices about the nature of the objectives the organization pursues;

2. Choices about how individuals are motivated to pursue these objectives;

3. Choices about how activities are coordinated in the organization;

4. Choices about how decisions are made in the organization.

These four core sets of activities have been arranged in an operational framework, referred to as the management model framework. Each of the four core sets of activities of this management model framework has a spectrum of choices available stretching between two opposing polar principles, labeled by the framework authors, "traditional management” pole versus "alternative management” pole (Table 1). The various management models can be positioned over this spectrum of choices, within the two poles, for each of the four sets of activities, which will be detailed hereafter.

- Table $1-$

\section{Managing objectives}

On the one hand, managers could have clear sets of short-term goals (labeled by the framework's authors as "Goal setting/alignment" polar principle). Goal setting should improve performance by narrowing the field of vision and keeping people focused on a particular set of objectives (Locke and Latham, 2002; Soriano, 2008). Goal setting is one of the most influential paradigms in management, with its positive effects and side-effects (Barsky, 2007; Gary and Edwin, 2009; Laverty, 1996; Locke, 2004; Ordóñez et al., 2009; Soriano, 2008). 
On the other hand, managers could pursue oblique paths through the definition of higher-level and longer-term sets of objectives (labeled by the framework's authors as the "Obliquity" polar principle). Obliquity aims to balance individuals, organizations, and community interests by embracing paradoxes (Gonin et al., 2013; Kilmann, 1984).

\section{Enabling/managing individual motivation}

About the choices concerning individual motivation, on the one hand, managers could attempt to hire and retain good people by making extrinsic rewards, like salary, benefits, or bonuses, attractive (labeled by the framework's authors as the "Extrinsic" polar principle). By enforcing organizational commitment, they risk burnout, loss in autonomy, loss in creativity, work-family conflicts, and quantity over quality (Balkin et al., 2013; Cerasoli, 2012; Kuvaas and Buch, 2014; Malik and Butt, 2013).

On the other, managers could focus on intrinsic rewards, by, for example, looking at peer recognition, sentiment of personal achievement, feeling of contribution to society at large (labeled by the framework's authors as the "Intrinsic" polar principle). This orientation seems more oriented to public services and non-profit organizations (Dozer et al., 2014). Intrinsic motivation positively relates, among others, to affective organizational commitment (Kuvaas and Buch, 2014) radical creativity (Malik and Butt, 2013) and quality over quantity (Cerasoli, 2012).

\section{Coordinating/managing across activities}

As concerns the choices about coordination, the traditional pole refers to managers who could exploit formal and well-structured management processes (labeled by the framework's authors as the "Bureaucracy" polar principle). Bureaucracy would constitute the most efficient and rational way in which one can organize human activity, giving form to systematic processes and organized hierarchies necessary to maintain order, maximize efficiency and eliminate favoritism (Weber, 1983) at the risk of threatening individual freedom, and losing employee involvement (Adler, 1999).

The alternative pole relates to managers who could encourage informal and spontaneous coordination processes (labeled by the framework's authors as the "Emergence" polar principle). This informal coordination seems important in cross-disciplinary knowledge creation (Sargent, 2013), within the organization (Ben-Menahem et al., 2015) as well as among organizations (Vries et al., 2014). 


\section{Making/managing down decisions}

Finally, concerning decision making, on the one hand, managers could take their hierarchical responsibility and lever their own knowledge and experience (labeled by the framework's authors as the "Hierarchy" polar principle). The subordinate submits to superiors' authority to decide how the work will be done and what other activities can be performed. In this way, conflicts are reduced, decisions and tasks can be imposed and accomplished, in particular when the decisions and tasks are not motivating ones (Makadok and Coff, 2009). One major inconvenience is that group performance and member satisfaction could be jeopardized (Bunderson et al., 2015).

On the other hand, the organizations could lever the disparate and collective knowledge of the personnel (labeled by the framework's authors as the "Collective wisdom” polar principle). Collective wisdom seems to facilitate innovations, better jobs, and idea creation (Birkinshaw, 2014, 2015; Keum and See, 2014; Sidle, 2007; Surowiecki, 2005; Keum and See, 2014; Zhu, 2009).

\section{Methodology}

The question by research as to what management models built on Permaculture concepts might look like is answered by a review of the literature on Permaculture for the scope, and on Birkinshaw and Goddard's management model framework for the pre-structured deductive analysis of the reviewed literature(Miles et al., 2013).

The review covers in particular the books and the journal articles on Permaculture. Google Scholars has been employed to identify the basket of publications to review. The Google Scholars query, launched on November 2013, retrieved 155 documents with 'Permaculture' in their titles. Inspired by a previous literature review specifically on Permaculture (Ferguson \& Lovell 2013), the search was confined to documents with the search term appearing in the title field. While this criterion excludes some works that could substantively pertain to Permaculture, the restriction on the title avoids including works for which the relationship with Permaculture could be ambiguous or trivial (Ferguson and Lovell, 2013).

Moreover, the term Permaculture was largely accepted as copyrighted within the Permaculture community (Henkel, 2015), even though the term never obtained a legal copyright protection. In addition "Permaculture" and its main training program, the "Permaculture Design Course", were, for a while, a service mark in the US and in Australia and a trademark in Australia. These protection attempts and experiences circumscribed the 
usage of the term "Permaculture" to documents that followed the founders' principles and ethics (Henkel, 2015).

In addition, apparently related terms like agro-ecology, sustainable agriculture, or organic farming are only superficially related to Permaculture. Agro-ecology is a promising alternative to industrial agriculture, with the potential to avoid the negative social and ecological consequences of input-intensive production. Nevertheless, agro-ecology includes a very wide and heterogeneous set of different movements: sustainable agriculture, organic farming and Permaculture are, to a certain extent, all agro-ecological movements, but each one has its distinct characteristics. Permaculture is said to be characterized by its unique approach to system design (Ferguson and Lovell, 2013), which cannot be found in other agroecological movements. Its unique system design approach is supposed to make Permaculture applicable beyond agricultural domains and hence a possible building ground for innovative management models. Its unique system design approach brought us to exclude terms and concepts like "agro-ecology”, "sustainable agriculture” or “organic farming” as search terms.

In practice, only 84 different publications were effectively identified: 22 journal articles, 11 books, 8 book chapters, 11 conference papers, 5 magazine articles, 13 reports and 14 theses. The remaining 71 results were double entries, self-published and exclusively electronic texts (like blog entries), missing documents, pages no longer online, misspelling returns, and other irrelevant results.

Among the journal articles, one was a literature review on Permaculture written by Ferguson \& Lovell (2013). Ferguson \& Lovell reviewed the literature searching, in addition to Google Scholar, on Web of Knowledge, International Information System for the Agricultural Sciences and Technology, and Education Resource Information Centre. For these three knowledge bases, Ferguson's search looked at publications with Permaculture appearing in any field. The final list of publications reviewed in this study integrates the 11 books and the one scientific article cited in this recent literature review, having "Permaculture" in the title that were absent from the Google Scholars query.

The 46 publications have been read in full (see Appendix for the full list of the references). The text of each document has been coded following qualitative pre-structured deductive analysis guidelines (Miles et al., 2013). We defined four codes, one code for each set of activities characterizing the management model, sticking on their original definitions: managing objectives, enabling/managing individual motivation, coordinating/managing 
across activities, making/managing down decisions.

For each publication, we gathered all the chunks of text associated with a specific code. Subsequently, for each coded set of activities, we interpret the meaning of these chunks of text to position each publication along the two poles ("Traditional" versus "Alternative" management poles) of the management model framework. For each set of activities, the publication was labeled with the name of a pole if two conditions were satisfied: (1) the publication included at least one chunk of text related to that specific pole and (2) the publication did not include any chunk of text related to the opposite pole. The publication was labeled with the names of the two poles if the publication included chunks of text related to both poles. The publication was not labeled if the publication did not include any chunk of text related to the coded set of activities.

In the end, we obtained a matrix (available in the Appendix), with the 46 publications, listed by line, and the four sets of activities, by column. At the intersection of the columns and lines, there are the names of the poles of the management model framework and an example of a quotation (or NA if no chunk of text related to the coded set of activities was available in the publication). At the bottom of the matrix a count of the number of publications that have been positioned along the two poles is proposed. We demonstrate the positioning for each set of activities, at first, leveraging the Permaculture founding authors, Mollison and Holmgren, second, looking for the other Permaculture authors, third, giving some significant transcripts coming from the reviewed publications and, at the end, reporting an illustration found in a reviewed publication.

\section{Results}

The results of the literature highlight that about one half of the publications (24 out of our basket of 46) do propose sentences related to at least one set of activities characterizing the management models. The other half of the publications (22 out of the 46) do not make any statement about any of the four sets of activities defining the management models based on our adopted framework. This second half of publications is, in general, focused on agronomic aspects of Permaculture. Looking at the publications proposing sentences related to at least one set of activities characterizing the management models, the counting of their positioning clearly highlights the orientation of Permaculture toward one of the two polar principles for each set of activities (Table 2). 
The poles are:

1. the obliquity of the objectives the organization pursues,

2. the intrinsic motivation of the individuals to pursue these objectives,

3. the emergence of the coordination of the activities in the organization,

4. the collective wisdom in the decision making.

These four poles are all from the "Alternative" management pole. Hence, Permaculture publications could be classed within the alternative management publications. No publication exclusively contradicts this orientation of Permaculture toward the alternative management pole, in so far as no publication includes only chunks of text related to the traditional Western opposite pole of management models. Only a small set of publications includes chunks of text related to both the poles, arguing that the preference toward one pole or the other definitively depends on contextual factors. Hence, a clear message comes out of the publications and this message will be detailed for each of the four activities of the management model framework.

\section{Managing objectives: obliquity}

Mollison and Holmgren seem to favor obliquity in managing objectives, levering a policy of personal responsibility (Mollison, 1988). They seem to be, nevertheless, aware of the limits of the personal responsibility policy given the limits and contingencies of our liberty of action:

"Personal responsibility implies full awareness of the structure of our individual dependence on, and effect on, the local and the global environment, and local and global communities” (Holmgren, 2002, p. 83).

This means that we should accept "personal responsibility for our situation as far as possible" (Holmgren, 2002, p. 6).

A large majority of the other authors appear to agree on obliquity in managing objectives. This obliquity would be set by considering themselves not only as beneficiaries, or even as managers, but as members of the biotic community (Hannis, 2011) and the global eco-village movement, committed to exploring an alternative paradigm to the dominant one (Veteto and Lockyer, 2008). 
For example, at Earthaven, an eco-village settlement nesting in the eastern slopes of the southern Appalachians (USA), the members created a Forestry Cooperative with the aim of allowing villagers and neighbors to create shelters, "freeing themselves from the clutches of banks and clear-cutting timber barons while keeping materials and money within the village economy” (Veteto and Lockyer, 2008, p. 47). At the very beginning of this settlement, the village founders did not fix any short-term goal, but they spent over a year observing their property, becoming familiar with the flows of energies before they began developing the ecovillage (Veteto and Lockyer, 2008).

\section{Enabling/managing individual motivation: intrinsic}

Mollison and Holmgren's propositions give the impression that individual motivation is intrinsically empowered by a personal responsibility policy and self-reliance:

"The prime directive of Permaculture: the only ethical decision is to take responsibility for our own existence and that of our children. Make it now” (Mollison, 1988, p. 1).

For them, intrinsic motivation would dismantle addictive and dysfunctional behaviors and the authors suggest self-reliance as a possible leverage to attain it:

"Self-reliance tends to work as a more generalised and invisible consumer boycott, undermining the market share and psychosocial dominance of the centralised and large-scale economies that support and maintain addictive and dysfunctional behaviour. At the same time, it tends to foster and stimulate new local forms of economic activity” (Holmgren, 2002, p. 87).

The individual motivation seems to remain intrinsically enabling also in the other authors. For them, Permaculture would be "not a self-imposed penance but a process of liberation" (Falk, 2013), entailing a review of personal values to emphasize the affordable as well as the postmaterialist rewards of living closer to nature.

For example, the literature (Hannis 2011) highlights that in England (UK) many potential Permaculture entrepreneurs are intrinsically motivated to propose low-impact development projects and to enjoy the low-income post-materialist rewards of living closer to the land. Unfortunately, their Permaculture projects are rejected by the British planning system as their business projects are considered not to be sufficiently efficient, money-making, profitable and market-oriented businesses (Hannis, 2011). 


\section{Coordinating/managing across activities: emergence}

For Mollison and Holmgren, "Permaculture emphasises bottom-up redesign processes" (Holmgren, 2002, p. XVI). Bureaucracy is mistrusted, leading to the suggestion to "remain skeptical of official authority and formal qualification in any field” (Holmgren, 2002, p. 47). The founding authors suggest even that the development of models of management built on Permaculture concepts could have a transformative impact on society. They propose that:

"Self-organisation, within complex systems, results in activity, structures, and behaviours that clearly emerge from within the system but have the effect of either transforming it or producing some completely new system” (Holmgren, 2002, p. 265).

Anyway, this bottom-up approach appears to be not ideological (Holmgren, 2002), as they prefer “discomfort, especially ethical discomfort... to ideological certainty” (Holmgren, 2002, p. XXV).

The large majority of the other authors seem to insist on emergence for coordinating across activities:

“The real solutions are in front of each of us - they cannot be outsourced to 'experts'. Disempowerment has no place in a living future. So become your own expert” (Falk, 2013, p. 259).

This rejection of the idea of the rarity of expertise could be balanced by the expertise of everyone grounded in situated practice and experience (Stevens, 2009).

For example, the literature (Falk 2013) publicizes that Falk's Permaculture enterprise, against the dominant agronomic ideas and standards, appears to have been able to find small and local solutions to revive a worn-out hill farm in Vermont (USA). They were capable of growing rice, where it was considered impossible by agronomic experts, given the cold climate, and they learnt from the observation and interaction with nature how to produce many other unexpected vegetables (Falk, 2013). 


\section{Making/managing down decisions: collective wisdom}

For Mollison and Holmgren, hierarchy should be considered to be a consequence of the energy-intensive society. Taking a humble posture, the authors estimate that "we simply do not have the wisdom to occupy the higher levels (of the social hierarchy)” (Holmgren, 2002, p. 79). Hence, they conclude on the development of a flatter social structure, based on "a million villages to replace nation-states [as] the only safe future for the preservation of the biosphere” (Mollison, 1988). These villages would self-organize and be self-sufficient:

"People are the only critical resource needed by people. We ourselves, if we organise our talents, are sufficient to each-other” (Mollison, 1988, p. 1).

Collective wisdom seems confirmed as the proposed solution for managing decisions, by the other authors. The only hierarchy that should count would be about priorities:

"There are no hierarchies of decision-making but there are hierarchies of function of work: where everyone agrees that some issues are very important and some more important than others" (Morrow, 2010, p. 254).

The "community will only work if it is designed BY all these different people, rather than FOR them” (Bell et al., 2005, p. 102).

The literature (Leahy 2009) proposes an example in South Africa, where Permaculture seems to have been levered to enhance the ecological sustainability of the South African villages, where the central government plans miserably failed. It seems that it was through bottom-up collective participation and everyone's involvement that suitable farming solutions emerged, improving the living conditions of the poor villagers (Leahy, 2009).

\section{Implications for innovating for a better world}

The evidence from the literature review highlights the extent to which the scope of Permaculture is largely beyond the agricultural practices. If one half of the publications were only focused in agronomic aspects, the other half covered the set of activities that characterizes the management models based on the adopted management model framework.

This evidence is in line with the previous statements on Permaculture, not only as the "permanent agriculture" portmanteau, but more as a permanent culture (Permanent Culture Now, 2014; Pezrès, 2010).

This extension in scope of Permaculture highlights the room for possible innovative 
management models built on the Permaculture concepts. Almost all the Permaculture authors, covering the four sets of activities characterizing the management models, propose an unambiguous orientation toward the same management model pole. This orientation is substantially stable throughout all their publications, from the seminal publication (Mollison and Holmgren, 1978) to the most recent one (Suh, 2014). Throughout all the publications no shift or radical misalignment appears on the choices covering how the four core sets of activities should be delivered. Only a handful of publications were ambiguous in their orientation evoking the need to take into consideration the contextual factors before being able to orient toward one pole or to the other pole of the management model framework. These small set of authors align with the critics of the management models based on the contingency of management and excluding any possibility for structural changes to management (Hamermesh, 1996; Mintzberg, 2006, 2011).

Beyond these criticisms, it appears that possible innovative management models built on the Permaculture concepts could be classed within the alternative management poles. They would be in line with the foreseen evolution of the management models in the future (Birkinshaw, 2010) towards the alternative management poles of the management model framework. Hence, alternative management models could be found in sport teams, social communities, aid organizations, families (Birkinshaw, 2010), and in Permaculture, too. Indeed, Permaculture management models, like the other alternative management models, are expected (Birkinshaw 2010) to be able to go beyond industrial management's short-sighted practices. They should encompass comprehension of the Earth's limited resources and aim at sustainable enterprise model innovations and sustainability in general.

By privileging obliquity, Permaculture would value organizational citizenship (Soriano, 2008) and ethical behaviors (Barsky, 2007) over short term economic performance with the aim of balancing individuals, organizations, and community interests (Gonin et al., 2013). Short term economic performance is 'simply' conceived as a means to social and ecological ends. Hence, any economic initiative should be explicitly designed to respond effectively and efficiently to some clear social and ecological ends. On the contrary, any economic initiative should be promptly discontinued if it is no longer socially or ecologically useful (Landua and Roland, 2013).

As concerns the choices about individual motivation, Permaculture is supposed to privilege intrinsic motivation, levering affective organizational commitment (Kuvaas and Buch, 2014), autonomy, radical creativity (Malik and Butt, 2013) and quality over quantity (Cerasoli, 
2012). In this way Permaculture is said to get closer to the motivation choices that are more likely to be found in public services and non-profit organizations (Dozer et al., 2014). The obliquity of the objective makes the organizational stakes clear in terms of the satisfaction of social and ecological ends. The Permaculture long term objectives and the ethical principles could be the foundations of this intrinsic individual motivation. Moreover, in as much as the Permaculture organizations see the short term economic objectives simply as means to longer term social and ecological ones, it could be that, for affinity reasons, the people involved in Permaculture organizations consider, at the same time, many short term extrinsic economic incentives as irrelevant or even disturbing.

Preferring emergent coordination, Permaculture may offer informal and spontaneous coordination processes, which seems particularly important in cross-disciplinary knowledge creation, which could be regularly the case when a holistic approach is applied (van Marrewijk \& Werre 2003). This emergent coordination could be within the organization's boundaries, but it is expected also at the inter-organizational level. This approach creates space for the emergence of bottom-up innovations, which could be closer to local opportunities and needs, from ecological, social and economic perspectives.

Finally, favoring collective wisdom over hierarchy concerning decision making, Permaculture is supposed to facilitate innovations, better jobs, idea creation (Keum \& See 2014; Sidle 2007; Surowiecki 2005), and, at the same time, question traditional values (Falk, 2013; Zhu, 2009). The preference for collective wisdom over hierarchy would reduce the hierarchical distances and would make the organizations flatter if not simply and completely flat: all the members would be peers without subordinates. This orientation, combined with emergent coordination, facilitates the involvement of people outside the organization in making its decisions and so integrate it better into the rest of the society.

\section{Ethical bases and design principles for management innovation}

Permaculture, with its strong ethical bases and unique design system, could hence be a contributor to the social transformation (Mirvis and Bradley, 2006) to create better and more integrated social, environmental and economic enterprises. It is important to recall that the Permaculture ethical bases are not related to the agronomic sphere and can be adopted by any organization to guide their strategic as well as operational activities. These ethical bases call for ecology, by caring for the earth and recognizing its bio-physical limits, and for humanism, 
by caring for people and for the redistribution of the surpluses. The economic surplus is evidently not an aim for itself, but a possibility for fairly sharing these surpluses. As a consequence, on the one hand, Permaculture can be seen as "part of a long tradition of concepts that emphasize mutualistic and symbiotic relationships over competitive and predatory ones” (Holmgren, 2002, p. 156). On the other hand, what makes it unique is its design principles.

Nonetheless, in order to think of and apply these revolutionary ethical bases, "the emergence of design as a universal skill alongside those of literacy and numeracy” (Holmgren, 2002, p. 14) is considered required. The strength of these design principles is in their holistic approach (Ferguson \& Lovell 2013), making them applicable in any kind of organization (Bulut and Yılmaz, 2008). They are: observe and interact, catch and store energy, obtain a yield, apply self-regulation and accept feedback, use and value renewable resources and services, produce no waste, design from patterns to details, integrate rather than segregate, use small and slow solutions, use and value diversity, use edges and value the marginal, creatively use and respond to change (Holmgren, 2002). These principles could be the engines of change elucidating "how" to link the sources of change with the objects of change (Zollo et al. 2013). These ethical bases and design principles may offer an additional set of tools to the members of the organizations for managing the innovation processes. The recognition of the importance, effectiveness and applicability of these principles would enhance the organizational capabilities in responding to external expectations about ecological, social and economic concerns (Safarzyńska et al. 2012). Permaculture as management innovation has the potential to engage business organizations more substantively to avert, and reverse their negative impact on society, going as far as creating regenerative enterprises (Landua and Roland, 2013; Rhodes, 2012).

\section{Implications for practice}

Our findings have important managerial implications for practice. On the one hand, Permaculture could be a potential inspiration for organizations willing to privilege long term objectives, intrinsic motivation, emergence of coordination and collective wisdom over short term objectives, extrinsic motivation, bureaucracy and hierarchy. Beyond the Permaculture inspiration, organizations could find principles, methodologies and illustrations of pioneering initiatives in Permaculture literature for the design of their strategies and their management models. Managers looking for more direct experience and practice could register with one of the many Permaculture Design Courses around the world. They are delivered by Permaculture 
certified teachers and would provide, at the same time, the basics on the Permaculture system design and a space for each participant to design his own change initiative or management model.

\section{Conclusion}

Exploring the ways in which innovation can serve to create better and more integrated social, environmental and economic enterprises is a big challenge. This article contributes to this challenge by exploring the possible innovative management models built on the Permaculture concepts. This contribution comes from a review of the literature on Permaculture, levering the Birkinshaw and Goddard's management model framework (Birkinshaw \& Goddard, 2009a, 2009b) for a pre-structured deductive analysis (Miles et al., 2013) of the selected publications.

The results of the literature highlight the orientation of Permaculture toward one of the two polar principles for each set of activities: (1) the obliquity of the objectives the organization pursues, (2) the intrinsic motivation of the individuals to pursue these objectives, (3) the emergence of the coordination of the activities in the organization, (4) the collective wisdom in the decision making. These four poles are all from the "Alternative" management pole (Birkinshaw \& Goddard, 2009a, 2009b). Hence, Permaculture management models could be classed within the alternative management models.

As a consequence, the possible innovative management models built on the Permaculture concepts might be management models for organizations that are looking for new ways forward, toward sustainable enterprise model innovations and sustainability in general.

Even if the 46 reviewed publications seem to give a clear answer to what management models built on Permaculture concepts might look like, the research could be deepened by analyzing the publications citing the same 46 publications. This additional research effort would have the advantage of extending the sample of publications to other eventual relevant publications.

Finally, some publications have been recently brought to the public, evaluating the empirical performances and results of Permaculture economically (Guégan et al., 2013; Shepard, 2013) ecologically (Rhodes, 2012; Shepard, 2013) and socially speaking (Shepard, 2013). Nevertheless, these publications are still too few, justifying doubts about Permaculture as idealistic and difficult to implement (Marrewijk and Werre, 2003). Hence a thorough analysis of the performances and results of real organizations levering Permaculture concepts seems to be required to make Permaculture propositions more robust. 


\section{References}

Adler, P.S. (1999), “Building better bureaucracies”, The Academy of Management Executive, Vol. 13 No. 4, pp. 36-47.

Altieri, M.A. (1989), “Agroecology: A new research and development paradigm for world agriculture”, Agriculture, Ecosystems \& Environment, Vol. 27 No. 1-4, pp. 37-46.

Balkin, D.B., Roussel, P. and Werner, S. (2013), "Extrinsic Rewards and Autonomy: Implications for Rewarding Creativity”, Academy of Management Proceedings, Vol. 2013 No. 1, p. 12346.

Bane, P. (2012), The Permaculture Handbook: Garden Farming for Town and Country, New Society Publishers.

Barkema, H.G., Chen, X.-P., George, G., Luo, Y. and Tsui, A.S. (2015), "West Meets East: New Concepts and Theories”, Academy of Management Journal, Vol. 58 No. 2, pp. 460-479.

Barnosky, A.D., Hadly, E.A., Bascompte, J., Berlow, E.L., Brown, J.H., Fortelius, M., Getz, W.M., et al. (2012), “Approaching a state shift in Earth’s biosphere”, Nature, Vol. 486 No. 7401, pp. 52-58.

Barsky, A. (2007), “Understanding the Ethical Cost of Organizational Goal-Setting: A Review and Theory Development.”, Academy of Management Proceedings, Vol. 2007 No. 1, pp. 1-6.

Bell, G., Brick, Belamy, D., Mollison, B. and more, \& 1. (2005), The Permaculture Way: Practical Steps to Create a Self-Sustaining World, Chelsea Green Publishing, White River Junction, Vt.

Bell, G. and Bunker, S. (2004), The Permaculture Garden, Permanent Publications, East Meon, Hampshire, U.K.

Ben-Menahem, S., Krogh, G. von, Erden, Z. and Schneider, A. (2015), “Coordinating Knowledge Creation in Multidisciplinary Teams: Evidence from Early-Stage Drug Discovery”, Academy of Management Journal, p. amj.2013.1214.

Birkinshaw, J. (2010), “The Critical Need to Reinvent Management”, Business Strategy Review, Vol. 21 No. 1, pp. 4-11.

Birkinshaw, J. (2014), “Do we still need managers?”, Business Strategy Review, Vol. 25 No. 2, pp. 6-6. 
Birkinshaw, J. (2015), “What Lessons Should We Learn From Valve's Innovative Management Model?”, Journal of Organization Design, Vol. 4 No. 2, pp. 8-9.

Birkinshaw, J. and Goddard, J. (2009a), “The management spectrum”, Business Strategy Review, Vol. 20 No. 4, pp. 30-35.

Birkinshaw, J. and Goddard, J. (2009b), “What Is Your Management Model?”, MIT Sloan Management Review, Vol. 50 No. 2, pp. 81-90.

Birkinshaw, J., Hamel, G. and Mol, M.J. (2008), “Management Innovation”, Academy of Management Review, Vol. 33 No. 4, pp. 825-845.

van den Bosch, F. (2012), On the Necessity and Scientific Challenges of Conducting Research into Strategic Value Creating Management Models, Erasmus Research Institute of Management - ERIM.

Bulut, Z. and Yılmaz, S. (2008), "Permaculture Playgrounds as a New Design Approach for Sustainable Society.”, International Journal of Natural \& Engineering Sciences, Vol. 2 No. 2, pp. 35-40.

Bunderson, J.S., Vegt, G.V. der, Cantimur, Y. and Rink, F. (2015), "Different Views of Hierarchy and Why They Matter: Hierarchy as Inequality or as Cascading Influence”, Academy of Management Journal, p. amj.2014.0601.

Burnett, G. and Strawbridge, B. (2008), Permaculture: A Beginner's Guide, Spiralseed, Westcliff On Sea, U.K.

Cazeloto, E. (2010), "Informatics monoculture, permaculture and construction of a counterhegemonic sociability - Monocultura informática, permacultura e a construção de uma sociabilidade contra-hegemônica”, MATRIZes, Vol. 3 No. 2, pp. 187-200.

Cennamo, C., Berrone, P. and Gomez-Mejia, L.R. (2008), “Does Stakeholder Management have a Dark Side?”, Journal of Business Ethics, Vol. 89 No. 4, pp. 491-507.

Cerasoli, C.P. (2012), “Incentives, Intrinsic Motivation, and Performance: A Meta-Analysis and Theoretical Reconciliation”, Academy of Management Proceedings, Vol. 2012 No. 1, pp. 1-1.

Clegg, S. (2014), “Managerialism: Born in the USA”, Academy of Management Review, Vol. 39 No. 4, pp. 566-576.

Corazon, S.S., Stigsdotter, U.K., Moeller, M.S. and Rasmussen, S.M. (2012), "Nature as 
therapist: Integrating permaculture with mindfulness- and acceptance-based therapy in the Danish Healing Forest Garden Nacadia”, European Journal of Psychotherapy \& Counselling, Vol. 14 No. 4, pp. 335-347.

Dearing, J.A., Wang, R., Zhang, K., Dyke, J.G., Haberl, H., Hossain, M.S., Langdon, P.G., et al. (2014), “Safe and just operating spaces for regional social-ecological systems”, Global Environmental Change, Vol. 28, pp. 227-238.

Domanigue, R. (1989), "Permaculture, an ecological design for diversified family farms”, American Journal of Alternative Agriculture, Vol. 4 No. 2, pp. 51-52.

Dozer, B., Palmer-Schuyler, J. “JP” and Rhiney, E. (2014), “It's About the Mission: Leadership and Public Service Motivation in Nonprofit Organizations”, Academy of Management Proceedings, Vol. 2014 No. 1, p. 11964.

Egri, C.P. and Herman, S. (2000), "Leadership in the North American Environmental Sector: Values, Leadership Styles, and Contexts of Environmental Leaders and their Organizations”, Academy of Management Journal, Vol. 43 No. 4, pp. 571-604.

Falk, B. (2013), The Resilient Farm and Homestead: An Innovative Permaculture and Whole Systems Design Approach, Chelsea Green Publishing.

Ferguson, R.S. and Lovell, S.T. (2013), "Permaculture for agroecology: design, movement, practice, and worldview. A review”, Agronomy for Sustainable Development.

Frey, D. (2011), Bioshelter Market Garden: A Permaculture Farm, New Society Publishers, Gabriola Island, BC.

Gary, P.L. and Edwin, A.L. (2009), "Science and Ethics: What Should Count as Evidence Against the Use of Goal Setting?”, The Academy of Management Perspectives, Vol. 23 No. 3, pp. 88-91.

Gonin, M., Besharov, M.H.-P. and Smith, W.K. (2013), "Managing Social-Business Tensions: A Review and Research Agenda for Social Enterprises”, Academy of Management Proceedings, Vol. 2013 No. 1, p. 11745.

Guégan, S., Léger, F., Chapelle, G. and Hervé-Gruyer, C. (2013), Maraîchage Biologique Permaculturel et Performance Économique, No. 2, Sciences pour l'Action et le Développement : Activités, Produits, Territoires, Paris, France, p. 26.

Guillén, M. (1994), Models of Management: Work, Authority, and Organization in a 
Comparative Perspective.

Hamermesh, R.G. (1996), "Fad-Free Management: The Six Principles That Drive Successful Companies and Their Leaders”.

Hannis, M. (2011), “Land-use planning, permaculture and the transitivity of 'development””, International Journal of Green Economics, Vol. 5 No. 3, pp. 269-284.

Hemenway, T. (2009), Gaia’s Garden: A Guide to Home-Scale Permaculture, Chelsea Green Publishing.

Henkel, M. (2015), 21st Century Homestead: Sustainable Agriculture I, Lulu.com.

Hill, C.W.L. and Jones, T.M. (1992), “Stakeholder-Agency Theory”, Journal of Management Studies, Vol. 29 No. 2, pp. 131-154.

Holmgren, D. (2002), Permaculture: Principles \& Pathways beyond Sustainability, Holmgren Design Services, Hepburn, Vic.

Holzer, S. and Sapsford-Francis, A. (2010), Sepp Holzer's Permaculture: A Practical Guide to Small-Scale, Integrative Farming and Gardening, Chelsea Green Pub., White River Junction, VT.

Jackson, T. (2008), Prosperity without Growth, University of Surrey, UK, Surrey, UK.

Jungck, J.R. (1985), “Perennial Polyculture, Permaculture and Preservation: The Principle of Diversity”, The American Biology Teacher, Vol. 47 No. 2, pp. 72-75.

Keum, D.D. and See, K.E. (2014), “The Influence of Hierarchy on Innovation and Idea Selection: A Process View”, Academy of Management Proceedings, Vol. 2014 No. 1, p. 10283.

Kilmann, R.H. (1984), Beyond the Quick: Managing Five Tracks to Organizational Success, Beard Books.

Knippenberg, D. van, Dahlander, L., Haas, M.R. and George, G. (2015), “Information, Attention, and Decision Making”, Academy of Management Journal, Vol. 58 No. 3, pp. 649657.

Koji, I. (2005), “Permaculture, Eco-village and BioRegionalism”, Environmental Information Science, Vol. 34 No. 1, pp. 26-30.

Kuvaas, B. and Buch, R. (2014), “Is Extrinsic Motivation Good or Bad, or Doesn’t it 
Matter?”, Academy of Management Proceedings, Vol. 2014 No. 1, p. 13587.

Landua, G. and Roland, E.C. (2013), Regenerative Enterprise, 8 Forms of Capital.

Laverty, K.J. (1996), “Economic 'Short-Termism': The Debate, The Unresolved Issues, and The Implications for Management Practice and Research”, Academy of Management Review, Vol. 21 No. 3, pp. 825-860.

Law, B. (2001), The Woodland Way: A Permaculture Approach to Sustainable Woodland Management, Permanent Publications.

Leahy, T. (2009), Permaculture Strategy for the South African Villages: Towards MDG 7 Environmental Sustainability, PI Productions Photography for Terry Leahy.

Liu, D., Liao, H. and Loi, R. (2012), “The Dark Side of Leadership: A Three-Level Investigation of the Cascading Effect of Abusive Supervision on Employee Creativity", Academy of Management Journal, Vol. 55 No. 5, pp. 1187-1212.

Locke, E.A. (2004), “Guest editor's introduction: Goal-setting theory and its applications to the world of business”, The Academy of Management Executive, Vol. 18 No. 4, pp. 124-125.

Locke, E.A. and Latham, G.P. (2002), “Building a practically useful theory of goal setting and task motivation: A 35-year odyssey”, American Psychologist, Vol. 57, pp. 705-717.

Lockyer, J. and Veteto, J.R. (2013), Environmental Anthropology Engaging Ecotopia: Bioregionalism, Permaculture, and Ecovillages, Berghahn Books.

Macnamara, L. and Storch, R. (2012), People \& Permaculture: Caring \& Designing for Ourselves, Each Other \& The Planet, 1 edition., Permanent Publications.

Makadok, R. and Coff, R. (2009), "Both Market and Hierarchy: An Incentive-System Theory of Hybrid Governance Forms”, Academy of Management Review, Vol. 34 No. 2, pp. 297-319.

Malik, M.A.R. and Butt, A.N. (2013), “The Next Step in Reward Creativity Research”, Academy of Management Proceedings, Vol. 2013 No. 1, p. 15887.

Mannen, D., Hinton, S., Kuijper, T. and Porter, T. (2012), "Sustainable Organizing A Multiparadigm Perspective of Organizational Development and Permaculture Gardening”, Journal of Leadership \& Organizational Studies, Vol. 19 No. 3, pp. 355-368.

Marrewijk, M. van and Werre, M. (2003), "Multiple Levels of Corporate Sustainability”, Journal of Business Ethics, Vol. 44 No. 2-3, pp. 107-119. 
Mars, R. and Ducker, M. (2005), The Basics of Permaculture Design, Chelsea Green Publishing Company, White River Junction, VT.

McManus, B. (2010), “An Integral Framework for Permaculture”, Journal of Sustainable Development, Vol. 3 No. 3, p. P162.

Mehri, D. (2006), “The Darker Side of Lean: An Insider’s Perspective on the Realities of the Toyota Production System”, The Academy of Management Perspectives, Vol. 20 No. 2, pp. 21-42.

Michael, P. and Meacham, W. (2001), "Permaculture as a Design Modality for Healing and Regeneration: Design with a Deeper Agenda”, The Design Journal, Vol. 4 No. 2, pp. 42-49.

Miles, M.B., Huberman, A.M. and Saldaña, J. (2013), Qualitative Data Analysis: A Methods Sourcebook, Third Edition edition., SAGE Publications, Inc, Thousand Oaks, Califorinia.

Miller, J.H. (2001), “The Principles of Permaculture Design”, Korean Journal of Organic Agriculture, Vol. v. 9(4) pp. 53-69.

Mintzberg, H. (2006), “Taking Management on a Strategy Safari”, Business: The Ultimate Resource, Vol. 2.

Mintzberg, H. (2011), Managing, 01 edition., Financial Times/ Prentice Hall, Harlow.

Mirvis, P. and Bradley, G. (2006), “Stages of Corporate Citizenship”, California Management Review, Vol. 48 No. 2, pp. 104-126.

Mollison, B. (2003), The Foundation Year-Book The Permaculture Academy.

Mollison, B. and Holmgren, D. (1978), Permaculture 1: A Perennial Agriculture for Human Settlements, Tagari Publications, Tyalgum, NSW.

Mollison, B.C. (1979), Permaculture 2, Practical Design for Town and Country in Permanent Agriculture., Tagari.

Mollison, B.C. (1988), Permaculture: A Designer's Manual, Tagari Publications, Tyalgum, Australia.

Morrow, R. (2010), Earth User's Guide to Permaculture, 2nd Edition, Revised second edition edition., Permanent Publications, Hampshire, U.K.; White River Junction, VT.

Motesharrei, S., Rivas, J. and Kalnay, E. (2014), "Human and Nature Dynamics (HANDY): Modeling Inequality and Use of Resources in the Collapse or Sustainability of Societies”, 
Ecological Economics.

Moustaghfir, K. and Schiuma, G. (2013), “Knowledge, learning, and innovation: research and perspectives”, Journal of Knowledge Management, Vol. 17 No. 4, pp. 495-510.

Mukute, M. (2009), “Cultural historical activity theory, expansive learning and agency in permaculture workplaces”, Southern African Journal of Environmental Education, Vol. 26, pp. 150-162.

Newman, W.H. and Wallender, H.W. (1978), “Managing Not-for-Prof it Enterprises”, Academy of Management Review, Vol. 3 No. 1, pp. 24-31.

Ordóñez, L.D., Schweitzer, M.E., Galinsky, A.D. and Bazerman, M.H. (2009), “Goals Gone Wild: The Systematic Side Effects of Overprescribing Goal Setting”, The Academy of Management Perspectives, Vol. 23 No. 1, pp. 6-16.

Peeters, B. (2011), "Permaculture as Alternative Agriculture”, Kasarinlan: Philippine Journal of Third World Studies, Vol. 26 No. 1-2, pp. 422-434.

Permanent Culture Now. (2014), “Introduction to permaculture”, Permanent Culture Now.

Pezrès, E. (2010), “La permaculture au sein de l'agriculture urbaine : Du jardin au projet de société”, VertigO - la revue électronique en sciences de l'environnement, No. Volume 10 numéro 2.

Pueyo, S. (2014), “Ecological Econophysics for Degrowth”, Sustainability, Vol. 6 No. 6, pp. 3431-3483.

Rhodes, C.J. (2012), "Feeding and healing the world: through regenerative agriculture and permaculture”, Science Progress, Vol. 95 No. 4, pp. 345-446.

Safarzyńska, K., Frenken, K. and van den Bergh, J.C.J.M. (2012), “Evolutionary theorizing and modeling of sustainability transitions”, Research Policy, Vol. 41 No. 6, pp. 1011-1024.

Sargent, M. (2013), “Organizational languages, coordination, and firm structure”, Academy of Management Proceedings, Vol. 2013 No. 1, p. 14339.

Senge, P.M., Smith, B., Kruschwitz, N., Laur, J. and Schley, S. (2008), The Necessary Revolution: How Individuals And Organizations Are Working Together to Create a Sustainable World, Crown Publishing Group.

Shenglei, P.I. and Feng, C. (2015), “Competitive Repertoire and Coordination of Chinese 
Horizontal Integrating Firms: Moderating Effects of Market Fragmentation”, International Business and Management, Vol. 10 No. 3, pp. 83-91.

Shepard, M. (2013), Restoration Agriculture: Real-World Permaculture for Farmers, Acres U.S.A., Austin, Texas.

Sidle, S.D. (2007), “Do Teams Who Agree to Disagree Make Better Decisions?”, The Academy of Management Perspectives, Vol. 21 No. 2, pp. 74-75.

Smith, M. (2002), “Supporting community and building social capital: Tools for navigating large social cyberspaces”, Communications of the ACM, Vol. 45 No. 4.

Smith, P., Syed, N., Wong, A. and Thaw, D. (2011), "When Machines Are Watching: How Warrantless Use of GPS Surveillance Technology Terminates The Fourth Amendment Right Against Unreasonable Search”, Lecturer and Other Affiliate Scholarship Series.

Soriano, D.R. (2008), “Can Goal Setting and Performance Feedback Enhance Organizational Citizenship Behavior?”, The Academy of Management Perspectives, Vol. 22 No. 1, pp. 65-66. Stevens, S.M. (2009), “The official rhetoric of permaculture: Motivating behaviour change through environmental communication”, Australian Journal of Communication, Vol. 36 No. 2, pp. 73-91.

Suh, J. (2014), “Towards sustainable agricultural stewardship: evolution and future directions of the permaculture concept”, Environmental Values.

Surowiecki, J. (2005), The Wisdom of Crowds, Reprint edition., Anchor, New York, NY.

Uragami, K. and Itonaga, K. (2000), “An evaluation of farmers lifestyle and space structure from the view of Permaculture design in the mid mountain villages.”, Journal of Rural Planning Association, Vol. 19 No. 2 Spec.Issue, p. 223.

Veteto, J.R. and Lockyer, J. (2008), “Environmental Anthropology Engaging Permaculture: Moving Theory and Practice Toward Sustainability”, Culture \& Agriculture, Vol. 30 No. 1-2, pp. 47-58.

Victor, P. (2008), Managing Without Growth.

Volberda, H.W., Van Den Bosch, F.A. and Heij, C.V. (2013), "Management innovation: Management as fertile ground for innovation”, European Management Review, Vol. 10 No. 1, pp. 1-15. 
Vries, T.A. de, Walter, F., Vegt, G. van der and Essens, P. (2014), “Governance and Effectiveness of Multi-Organizational Collaborations”, Academy of Management Proceedings, Vol. 2014 No. 1, p. 15500.

Weber, M. (1983), On Capitalism, Bureaucracy and Religion: Selection of Texts, translated by Andreski, S., George Allen \& Unwin, London ; Boston.

Whitefield, P. (2000), Permaculture In A Nutshell, Permanent Publications.

Whitefield, P. (2004), Earth Care Manual: A Permaculture Handbook for Britain \& Other Temperate Climates, Permanent Publications.

Whiteman, G., Walker, B. and Perego, P. (2013), "Planetary boundaries: Ecological foundations for corporate sustainability”, Journal of Management Studies, Vol. 50 No. 2, pp. 307-336.

Wurfel, M. (2013), “Roots, Tendrils, Sprouts and Shoots: A Case Study of Parkallen's Community Garden, a permaculture project”, Earth Common Journal, Vol. 3 No. 1.

Zhu, Y. (2009), “Philosophical Underpinnings for Equilibrium of Values and Implications for Management Education: A Response to Harold Leavitt”, Academy of Management Learning \& Education, Vol. 8 No. 2, pp. 290-296.

Zollo, M., Cennamo, C. and Neumann, K. (2013), "Beyond What and Why Understanding Organizational Evolution Towards Sustainable Enterprise Models”, Organization \& Environment, Vol. 26 No. 3, pp. 241-259 